\title{
A mild case of SMVT deficiency illustrating the importance of treatment response in variant classification
}

Ingeborg Hauth ${ }^{1}$, Hans R. Waterham ${ }^{2,3}$, Ronald JA Wanders ${ }^{2,3}$, Saskia van der Crabben ${ }^{3,4}$, Clara D.M. van Karnebeek ${ }^{3,4,5}$

${ }^{1}$ Department of Pediatrics (Metabolic Diseases), Amalia Children's Hospital, Radboud university Medical Center, Nijmegen, The Netherlands

${ }^{2}$ Laboratory Genetic Metabolic Diseases, Department of Clinical Chemistry, Amsterdam University Medical Centers - University of Amsterdam, The Netherlands

${ }^{3}$ United for Metabolic Diseases, The Netherlands

${ }^{4}$ Department of Human Genetics, University Medical Centers, University of Amsterdam, The Netherlands

5 Department of Pediatrics, Emma Children's Hospital, Amsterdam University Medical Centers, University of Amsterdam, The Netherlands +

All authors have approved the current version of the manuscript and its submission to CSH Molecular Case Studies.

\section{Correspondence to:}

Professor dr. C.D. van Karnebeek

Departments of Pediatrics \& Human Genetics,

Emma Children’s Hospital (Room H7-254), Amsterdam University Medical Centers

Meibergdreef 9, 1105 AZ Amsterdam, the Netherlands

Email: c.d.vankarnebeek@amsterdamumc.nl 


\begin{abstract}
Introduction

Sodium-dependent multivitamin transporter (SMVT) deficiency is a recently described multivitamin-responsive IMD of which the phenotypic spectrum and response to treatment remains to be elucidated. So far, four pediatric patients have been described in three case reports with symptoms ranging from severe neurodevelopmental delay to feeding problems and failure to thrive, who demonstrated significant improvement after initiation of enhancement of targeted multivitamin treatment (biotin, pantothenic acid and lipoic acid).
\end{abstract}

\title{
Case vignette of SMVT deficiency
}

We describe a fifth case of a patient presenting at the relatively mild end of the phenotypic spectrum with failure to thrive, frequent vomiting and metabolic acidosis with hypoglycemia, and mild osteopenia, who was diagnosed with SMVT deficiency due to compound heterozygous variants in SLC5A6. Additional genetic testing of variants of unknown significance (VUS) as well as the clinical improvement in all aspects of the patient's disease upon initiation of treatment with biotin and pantothenic acid (plus lipoate as anti-oxidant) aided in the confirmation of this diagnosis.

\section{Discussion}

This case report aims to enhance recognition of the broad phenotypic spectrum of SMVT deficiency due to SLC5A6 mutations, and discusses the different treatment strategies. It demonstrates how combining biochemical and genetic testing with the evaluation of (early) treatment response (i.e. using a 'diagnostic therapeuticum'), can influence confirmation of pathogenicity of genomic variants. 


\section{Introduction}

\section{Multivitamin responsive IMDs}

Inherited metabolic disorders (IMDs) comprise a continuously expanding class of rare genetic disorders, of which over 1500 have been identified since the first IMD alkaptonuria was proposed in 1902 by Sir Archibald Garrod (Garrod 1902; www.iembase.org). Due to the rapidly progressing developments in the field of genetics, with expanding knowledge of the underlying pathophysiology caused by the impairment in the metabolic pathway(s) involved, Ferreira et al. (2019; 2021) proposed an up-to-date nosology (International Classification of Inherited Metabolic Disorders, ICIMD, www.icimd.org), consisting of a hierarchical, group-based classification of all currently known IMDs. Within this classification, the disorders of vitamin and cofactor metabolism account for 73 IMDs, encompassing a relatively large, potentially treatable group of IMDs since vitamin supplementation is usually readily available and safe and has been proven to be very efficient, especially if given early on in the disease course (Ferreira and van Karnebeek 2019; Ferreira et al. 2021; Mandia et al. 2021). Therefore, timely recognition and knowledge of treatment strategies is paramount. Reviewing the treatment strategies of these 73 IMDs show that, thus far, only few of those IMDs are known to be multivitamin-responsive, i.e. treatable by supplementation of two or more vitamins. One example of such an IMD is biotin-thiamine-responsive basal ganglia disease (BTBGD), which is characterized by (subacute) encephalopathy, seizures and other neurological symptoms, presenting in childhood, early infancy or adulthood (Tabarki et al. 2013; Ortigoza-Escobar et al. 2014). Biotin and thiamine are given as early in the disease course as possible and are continued lifelong. Here, we present an illustrative case vignette of another such treatable multivitamin-responsive IMD: the recently reported sodium-dependent multivitamin transporter (SMVT) deficiency. The phenotype, genotype and treatment response of our patient are compared to other cases described in literature. By sharing knowledge and the diagnostic 
process of single cases affected by this rare disease and comparing treatment strategies we aim to pave the way for future recognition and treatment of SMVT-deficient patients. Moreover, it demonstrates the importance of phenotype enhanced genotyping.

\section{What do we know about SMVT deficiency currently?}

Among the disorders of vitamin metabolism, SMVT deficiency is a recently described inherited metabolic disorder with so far a broad phenotypic spectrum ranging from feeding problems, failure to thrive, metabolic acidosis and mild to severe neurological deficits. Responses to treatment differ between cases. SMVT is encoded by SLC5A6 located on chromosome 2p23.3. This transmembrane protein transports the water-soluble vitamins pantothenic acid (vitamin B5), biotin (vitamin B7) and the metabolite lipoate in the presence of sodium in both the digestive system and across the blood-brain barrier (Balamurugan et al. 2003; Sabui et al. 2018). Recessive variants in SLC5A6 causing SMVT deficiency is a recently described inherited metabolic disorder. Clinically, the disease mimics biotinidase deficiency with a broad phenotypic spectrum ranging from feeding problems, failure to thrive, metabolic acidosis and mild to severe neurological deficits (Schwantje et al. 2019).

Biotin is an essential micronutrient, vital in normal cellular metabolism, growth and development, as well as acting as essential cofactor in the different carboxylase enzymes known to be active in various metabolic pathways, including gluconeogenesis (pyruvate carboxylase), catabolism of amino acids (propionyl-CoA carboxylase and 3-methylcrotonyl-CoA carboxylase) and fatty acid synthesis (acetyl-CoA carboxylase) (McMahon 2002; Said 2012). In addition, biotin plays a role in energy metabolism, cellular oxidative stress regulation and gene expression, as well as enabling normal immune functioning (Madsen et al. 2015; Rodriguez-Melendez and Zempleni 2003). Deficiency of biotin can lead to a variety of clinical symptoms including failure to thrive, neurological disorders such as ataxia, developmental 
delay and seizures, impairment in bone development, as well as dermatological features (Mock et al. 1981; Wolf 2012; Ghosal 2013).

Pantothenic acid is also an essential micronutrient, functioning as a precursor of coenzyme A which in turn plays an indispensable role in fatty acid oxidation, and to a lesser extent in carbohydrate and protein metabolism (Lederer 1971; Said 2011). Pantothenic acid deficiency leads to disturbed intermediary metabolism, ie impairs CoA biosynthesis, stimulates polyolpathway activity, impairs glycolysis and tricarboxylic acid cycle activity and modifies urea metabolism, as evident on organic acid, amino acid and acylcarnitine profiles. Lipoate is one of the cofactors in the glycine cleavage system and the pyruvate dehydrogenase, branched chain ketoacid dehydrogenase and ketoglutarate dehydrogenase complexes. It catalyzes redox reactions in the mitochondrial energy production, enabling oxidative decarboxylation reactions of amino acids and keto acids, as well as providing anti-oxidative and anti-inflammatory effects (Morikawa et al. 2001). Lipoate deficiency is associated with encephalopathy and other neurological disorders as well as low bone density (Roberts 2015; Mayr 2011).

Ghosal et al. (2013) found that mice with intestine-specific deletion of SMVT either died prematurely or displayed significant growth retardation, decreased bone density and length, and lethargic behavior, compared to controls. Sabui et al. (2018) showed that intestinal-specific SMVT-knockout of the mouse was associated with growth retardation. They also developed spontaneous and severe inflammation causing early death. All clinical features were completely reversed by biotin and pantothenic acid supplementation.

\section{Case vignette of SMVT deficiency}

\section{Case report}

Our case is a currently 5-year-old girl. She was born as the first child to healthy, nonconsanguineous parents after an uncomplicated term pregnancy. She was noted as small for 
gestational age (SGA) at 2650 grams $(<\mathrm{P} 5)$, but further physical examination revealed no dysmorphic features or microcephalia. Soon after birth, feeding difficulties became apparent with frequent vomiting and failure to thrive. Antacid treatment was started for suspected gastroesophageal reflux disease, with temporary positive effect. Her psychomotor development was age-appropriate, albeit she was described as somewhat clumsy. She was easily fatigued apparently due to a lack of energy and had very dry, eczematous skin. Laboratory findings showed mild osteopenia for which suppletion of vitamin D and calcium was started. She was frequently hospitalized the first two years of her life due to persistent vomiting, diarrhea and insufficient oral intake resulting in dehydration and ketotic hypoglycemia requiring nasogastric (NG) or intravenous rehydration. From the age of 1,5 to 2 years old, she was fed through an NG and nasoduodenal (ND) tube. At 2 years of age she was admitted to the pediatric intensive

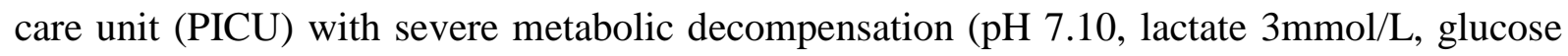
$1.7 \mathrm{mmol} / \mathrm{L}$, ketones $6 \mathrm{mmol} / \mathrm{L}$ ) in the course of a gastro-intestinal viral infection. She recovered from this episode but suffered from subsequent periods of cyclic vomiting with a tendency to ketoacidosis. Extensive additional testing was done, with high suspicion of an underlying metabolic disorder.

\section{Diagnostic confirmation and treatment}

Metabolic screening performed in plasma and urine showed nonspecific subtle elevations of various organic acids including 3-hydroxyisovaleric acid, lactic acid, and 3-hydroxybutyrate. Elevated lactate levels as observed in plasma and urine of the patient points to the impaired degradation of pyruvate and is a characteristic finding in patients with biotinidase deficiency as well as in patients with a defect in the biosynthesis of lipoic acid and in fact patients with a defect in the biosynthesis of coenzyme A as in PKAN2-deficiency. Furthermore, 3hydroxyisovaleric acid is one of these typical metabolites which is elevated in biotinidase 
deficiency. Chromosomal micro-array did not reveal pathogenic copy number variants. Triobased whole exome sequencing (trio-WES) was performed in the EN-ISO 15189:2012 certified clinical DNA diagnostics laboratory Amsterdam UMC Genome Diagnostics (AGDx). This revealed compound heterozygous potential pathogenic variants in SLC5A6 (NM_021095.4): c.1005+1G>A, predicted to affect splicing, and c.1865_1866del, introducing a shift of the reading frame (p.(Gln622Argfs*51)) (Table 1). Subsequent SLC5A6 cDNA analysis, performed on transcribed mRNA isolated from cultured primary skin fibroblasts of the patient, confirmed the incorrect splicing of intron 9 due to the c. $1005+1 G>A$ variant resulting in retention of 61 bp of intron 9 and predicted to result in a non-functional protein (p.(Phe336Serfs*57)). In addition, the mis-spliced allele was less abundant, which may be due to nonsense mediated mRNA decay (see supplementary figure). This variant was reported 1/152142 in gnomAD v3.1.2 (https:/gnomad.broadinstitute.org/) and 1/996 in the GoNL database (https://www.nlgenome.nl/). Based on these findings we classify the variant as pathogenic (PVS1, PS3_Supporting, PM3_Supporting, PM2_Supporting, PP4). The c.1865_1866del variant results in a shift of reading frame as a consequence of which the C-terminal 13 amino acids will be substituted by 50 other amino acids (p.(Gln622Argfs*51)). The C-terminus of SMVT is not well conserved among species so the consequences of this variant for protein functioning remain unclear. Because it was previously reported in another patient with SMVT deficiency (Schwantje et al. 2019), we considered this variant likely pathogenic (PM3, PM4, PM2_Supporting, PP4). Its frequency was reported 15/152128 in gnomAD v3.1.2.

Based on this diagnosis, our patient was started on oral supplementation of biotin, pantothenic acid and -as anti-oxidant- lipoic acid, which were gradually increased to once daily at doses of 15mg, 300mg and 300mg respectively. On this targeted multivitamin treatment, vomiting ceased. There have been no more metabolic decompensations or hospital admissions, even with 
subsequent infections. Growth and development have improved and normalized, as well as her overall condition and exercise tolerance. The positive response on vitamin supplementation confirms the clinical and genetic diagnosis.

\section{Comparison to other described SMVT deficiency cases}

To the best of our knowledge, only three other case reports have appeared in which SMVTdeficiency was reported due to pathogenic SLC5A6 variants (see Table 2 for a detailed comparison). Subramanian et al. (2017) describe a severely affected patient with significant developmental delay, failure to thrive, severe gastro-esophageal reflux, variable immunodeficiency and osteoporosis. After oral supplementation was started and eventually optimized, the infant improved in growth, verbal and motor development, and his immune status normalized.

Schwantje et al. (2019) presented a case of a then 3-year-old girl with a delay in gross motor development, frequent vomiting, chronic diarrhea and failure to thrive in the first years of life, accompanied by a delay in gross motor development. Oral treatment resulted in somatic growth normalization and resolution of diarrhea. However, so far her delay in motor development persisted.

Byrne et al. (2019) described two siblings with a profound neurodevelopmental delay during infancy, with progressive ataxia, dyskinesia and epilepsy. Severe reflux and failure to thrive were also present. At 2 years of age, one of the siblings died of acute gastro-intestinal hemorrhage following perforation of a duodenal ulcer. After initiating treatment of the second sibling, both neurological and gastro-intestinal symptoms improved.

\section{Discussion and future directions}

\section{Diagnostic difficulties and treatment strategies}


Confirmation of diagnosis in our case was established through a combination of strategies. RNA analysis was performed showing aberrant splicing of one of the SLC5A6 variants. Initiation of therapy by targeted supplementation of biotin, pantothenic acid and lipoic acid led to significant improvement of growth, development and overall condition, comparable to the other described cases. Although several enzymes require covalently-bound lipoamide, free lipoate is not capable of participating in this modification, at least in mammals. Indeed, the phenotype of the SVMT-deficient c-KO mouse is rescued by pantothenate and biotin without lipoate (Sabui et al., 2018). Oral administration of these supplements is well-tolerated and safe, and certainly less invasive; parenteral administration is indicated in case of vormiting, encephalopathy and/or possible metabolic decompensation.

She also had no further metabolic decompensations. In case of patients with a suspected inherited metabolic disorder but with only variants of unknown significance and/or likely pathogenic variants, in addition to performing further additional genetic testing, treating physicians could think about starting treatment in case potential benefits of treatment might outweigh the possible side-effects of treatment. In case treatment succeeds/diminishes clinical symptoms, preferably in different, but similar affected, not-related patients, we suggest this might be added to the classification of the identified genetic variants, in accordance with the paper by Shen et al (2020). Importantly, such early initiation of treatment can prevent further, irreversible, organ damage.

\section{Comparison to other described SMVT deficiency cases}

When comparing all 5 cases, all of the patients suffered from feeding difficulties, frequent vomiting and failure to thrive. The patients of Subramanian et al. and Byrne et al. were severely impaired neurologically, while our patient and that of Schwantje et al. were only described as being somewhat clumsy or with mild delays in gross motor development. This milder 
presentation may be related to the associated genetic variants (Byrne et al. 2019; Schwantje et al. 2019). The c.1865_1866del (p.(Gln622Argfs*51)) variant, shared by both patients, is predicted to only affect the extreme C-terminus of the encoded protein and thus likely results in a protein with residual catalytic activity. Unfortunately, the activity of the protein cannot be easily assessed to confirm this. All patients except one, the first and deceased sibling described by Byrne et al., have received treatment since diagnosis. Dosages were based upon the initial case description by Subramanian et al., with some variation. Subramanian et al. suggest that in case of impaired intestinal absorption or cellular uptake of biotin and pantothenic acid (and lipoic acid), as in SMVT deficiency, uptake of these nutrients by different cells at high supraphysiologic concentrations occurs via simple diffusion, thereby (at least partially) ameliorating the SMVT system. It is notable that the reported cases which were mild in nature - ie Schwantje et al (2019) and the current patient- experienced metabolic decompensations while the (other) more severe cases did not. There are several possible explanations including variability in environmental triggers and severe intercurrent illness, as well as a difference in available clinical history data, i.e. decompensations may have been missed.

\section{Methods}

Medical and laboratory records were searched for data collection and extraction. DNA extraction and RNA analysis was performed according to the methods described by Maxit et al. in 2017.

\section{Additional information}

\section{Data Deposition and Access}

Data on the variants and phenotype are deposited in ClinVar and can be found under accession numbers scv002097395 and scv002097396. 


\section{Ethics Statement}

Parents of the patient have provided written consent for publication of this case report.

\section{Acknowledgments}

The authors gratefully acknowledge the patient and parents for their participation in this study, and the clinicians and laboratory specialists for management of this patient.

\section{Author Contributions}

Ingeborg Hauth: collected clinical and genetic, wrote the first draft, revised and finalized the manuscript.

Saskia van der Crabben: contributed to patient phenotyping and diagnosis, supervised data collection and drafting of the manuscript.

Hans Waterham: performed the genetic variant interpretation and RNA studies, contributed to drafting and revision of the manuscript.

Ronald Wanders: performed the biochemical and metabolic data interpretation, contributed to drafting and revision of the manuscript.

Clara van Karnebeek: designed the study, supervised patient diagnostics, treatment and followup, supervised data collection and drafting and revision of the manuscript.

\section{Funding}

This work was supported by Stichting Metakids, The Netherlands.

\section{Conflict of interests}

The authors declare no conflict of interest. 


\section{References}

Balamurugan K, Ortiz A, Said HM. 2003. Biotin uptake by human intestinal and liver epithelial cells: role of the SMVT system. Am J Physiol Gastrointest Liver Physiol 285: 73-77.

Byrne AB, Arts P, Polyak SW, Feng J, Schreiber AW, Kassahn KS. 2019. Identification and targeted management of a neurodegenerative disorder caused by biallelic mutations in SLC5A6. NPJ Genom Med 4. doi.org/10.1038/s41525-019-0103-x.

Ferreira CR, van Karnebeek CDM, Vockley J, Blau N. 2019. A proposed nosology of inborn errors of metabolism. Genet Med 21: 102-106.

Ferreira CR, Rahman S, Keller M, Zschocke J. 2021. An international classification of inherited metabolic disorders (ICIMD). J Inherit Metab Dis 44: 164-177.

Garrod AE. 1902. The incidence of alkaptonuria: a study in chemical individuality. The Lancet 160: 1616-1620.

Ghosal A, Lambrecht N, Subramanya SB, Kapadia R, Said HM. 2013. Conditional knockout of the Slc5a6 gene in mouse intestine impairs biotin absorption. Am J Physiol Gastrointest Liver Physiol 304: G64-G71.

Lederer WH, Kumar M, Axelrod AE. 1971. Effects of pantothenic acid deficiency on cellular antibody synthesis in rats. J Nutr 105: 17-25.

Madsen CT, Sylvestersen KB, Young C, Larsen SC, Poulsen JW, Andersen MA, Palmqvist EA, Hey-Mogensen M, Jensen PB, Treebak JT, et al. 2015. Biotin starvation causes 
mitochondrial protein hyperacetylation and partial rescue by the SIRT3-like deacetylase Hst4p. Nat Commun 6: 7726.

Maxit C, Denzler I, Marchione D, Agosta G, Koster J, Wanders RJA, Ferdinandusse S, Waterham HR. 2017. Novel PEX3 Gene Mutations Resulting in a Moderate Zellweger Spectrum Disorder. JIMD Rep 34: 71-75.

Mayr JA, Zimmermann FA, Fauth C, Bergheim C, Meierhofer D, Radmayr D, Zschocke J, Koch J, Sperl W. 2011. Lipoic acid synthetase deficiency causes neonatal-onset epilepsy, defective mitochondrial energy metabolism, and glycine elevation. American journal of human genetics 89: 792-797.

Mandia D, Shor N, Benoist J, Nadjar Y. 2021. Adolescent-Onset and Adult-Onset VitaminResponsive Neurogenetic Diseases: A Review. JAMA Neurol. doi:10.1001/jamaneurol.2020.4911.

McMahon RJ. 2002. Biotin in metabolism and molecular biology. Annu Rev Nutr 22: 221-239. Mock DM, deLorimer AA, Liebman WM, Sweetman L, Baker H. 1981. Biotin deficiency: an unusual complication of parenteral alimentation. N Engl J Med 304: 820-823.

Morikawa T, Yasuno R, Wada H. 2001. Do mammalian cells synthesize lipoic acid? Identification of a mouse cDNA encoding a lipoic acid synthase located in mitochondria. FEBS Lett 498: 16-21.

Ortigoza-Escobar JD, Serrano M, Molero M, Oyarzabal A, Rebollo M, Muchart J, Artuch R, Rodríguez-Pombo P, Pérez-Dueñas B. 2014. Thiamine transporter-2 deficiency: outcome and treatment monitoring. Orphanet journal of rare diseases 9: 92.

Richards S, Aziz N, Bale S, Bick D, Das S, Gastier-Foster J, Grody WW, Hegde M, Lyon E, Spector E, et al. 2015. Standards and guidelines for the interpretation of sequence variants: a joint consensus recommendation of the American College of Medical Genetics and Genomics and the Association for Molecular Pathology. Genet Med 17: 405-423. 
Roberts JL, Moreau R. 2015. Emerging role of alpha-lipoic acid in the prevention and treatment of bone loss. Nutrition Reviews 73: 116-125.

Rodriguez-Melendez R, Zempleni J. 2003. Regulation of gene expression by biotin (review). J Nutr Biochem 14: 680-690.

Sabui S, Kapadia R, Ghosal A, Schneider M, Lambrecht NWG, Said HM. 2018. Biotin and pantothenic acid oversupplementation to conditional SLC5A6 KO mice prevents the development of intestinal mucosal abnormalities and growth defects. Am J Physiol Cell Physiol 315: 73-79.

Said HM. 2012. Biotin: biochemical, physiological and clinical aspects. Subcell Biochem 56, $1-19$.

Said HM. 2011. Intestinal absorption of water-soluble vitamins in health and disease. Biochem J 437: 357-372.

Schwantje M, de Sain-van der Velden M, Jans J, van Gassen K, Dorrepaal C, Koop K, Visser G. 2019. Genetic defect of the sodium-dependent multivitamin transporter: A treatable disease, mimicking biotinidase deficiency. JIMD Reports 48: 11-14.

Shen JJ, Wortmann SB, de Boer L, Kluijtmans LA, Huigen MCDG, Koch J, Ross S, Collins CD, van der Lee R, van Karnebeek CDM et al. 2020. The role of clinical response to treatment in determining pathogenicity of genomic variants. Genetics in Medicine. https://doi.org/10.1038/s41436-020- 00996-9.

Subramanian VS, Constantinescu AR, Benke PJ, Said HM. 2017. Mutations in SLC5A6 associated with brain, immune, bone, and intestinal dysfunction in a young child. Hum Genet 136: 253-261.

Wolf B. 2012. Biotinidase deficiency: "If you have to have an inherited metabolic disease, this is the one to have”. Genet Med 14: 565-575. 


\begin{tabular}{|c|c|c|c|c|c|c|c|c|c|c|}
\hline Gene & Chromosome & $\begin{array}{l}\text { HGVS DNA } \\
\text { Reference }\end{array}$ & $\begin{array}{l}\text { HGVS Protein } \\
\text { Reference }\end{array}$ & $\begin{array}{l}\text { Variant } \\
\text { Type }\end{array}$ & $\begin{array}{l}\text { Predicted } \\
\text { Effect } \\
\text { (substitution, } \\
\text { deletion, etc.) }\end{array}$ & $\begin{array}{l}\text { dbSNP/dbVar } \\
\text { ID }\end{array}$ & $\begin{array}{l}\text { Genotype } \\
\text { (heterozygous/ } \\
\text { homozygous) }\end{array}$ & ClinVar ID & $\begin{array}{l}\text { Parent of } \\
\text { Origin }\end{array}$ & $\begin{array}{l}\text { Observed Effect (if } \\
\text { shown to be } \\
\text { different from } \\
\text { Predicted Effect) }\end{array}$ \\
\hline SLC5A6 & 2 & $\begin{array}{l}\text { c.1005+1C>T } \\
(\mathrm{NM} \text { 021095.4) }\end{array}$ & & $\begin{array}{l}\text { Splice } \\
\text { donor }\end{array}$ & Splicing defect & Rs565711489 & Heterozygous & SCV002097395 & Maternal & $\begin{array}{l}\text { retention of } 61 \mathrm{bp} \\
\text { of intron } 9 \\
\text { resulting in } \\
\text { p.(Phe336Serfs*57) }\end{array}$ \\
\hline SLC5A6 & 2 & $\begin{array}{l}\text { c.1865_1866del } \\
\text { (NM_021095.4) }\end{array}$ & p.(Gln622Argfs*51) & Deletion & Deletion & Rs774193816 & Heterozygous & SCV002097396 & Paternal & NA \\
\hline
\end{tabular}


Table 2

\begin{tabular}{|c|c|c|c|c|c|}
\hline \multicolumn{6}{|c|}{ Clinical features and treatments } \\
\hline Clinical features & $\begin{array}{l}\text { Subramani } \\
\text { an et al. } \\
2017\end{array}$ & $\begin{array}{l}\text { Schwantje et al. } \\
2019\end{array}$ & $\begin{array}{l}\text { Byrne et al. } \\
2019 \text { I-1 }\end{array}$ & $\begin{array}{l}\text { Byrne et al. } \\
2019 \text { I-2 }\end{array}$ & This study \\
\hline \multicolumn{6}{|l|}{ Neurological } \\
\hline $\begin{array}{l}\text { Neurocognitive } \\
\text { regression }\end{array}$ & $\begin{array}{l}\text { Yes, onset } \\
\text { infantile }\end{array}$ & No & $\begin{array}{l}\text { Yes, onset } \\
14 \text { months }\end{array}$ & $\begin{array}{l}\text { Yes, onset } 12 \\
\text { months }\end{array}$ & No \\
\hline Microcephaly & Yes & No & Yes, relative & Yes, relative & No \\
\hline Spasticity & Yes & No & No & No & No \\
\hline $\begin{array}{l}\text { Gross motor } \\
\text { development }\end{array}$ & $\begin{array}{l}\text { Profound } \\
\text { delay }\end{array}$ & Delayed & $\begin{array}{l}\text { Profound } \\
\text { delay }\end{array}$ & $\begin{array}{l}\text { Profound } \\
\text { delay }\end{array}$ & $\begin{array}{l}\text { Normal, but } \\
\text { clumsy }\end{array}$ \\
\hline Seizures & NR & No & No & Yes & No \\
\hline $\begin{array}{l}\text { Peripheral } \\
\text { neuropathy }\end{array}$ & NR & No & NR & $\begin{array}{l}\text { Yes, mixed } \\
\text { demyelinating } \\
\text { and axonal } \\
\text { sensorimotor } \\
\text { polyneuropath } \\
\text { y }\end{array}$ & No \\
\hline Neuroimaging (MRI) & $\begin{array}{l}\text { Cerebral } \\
\text { atrophy } \\
\text { Brainstem } \\
\text { (pontine) } \\
\text { atrophy } \\
\text { Thin corpus } \\
\text { callosum }\end{array}$ & $\begin{array}{l}\text { No } \\
\text { abnormalities }\end{array}$ & $\begin{array}{l}\text { No cerebral } \\
\text { atrophy } \\
\text { Right } \\
\text { cerebellar } \\
\text { hemorrhagic } \\
\text { foci } \\
\text { T2/FLAIR } \\
\text { signal } \\
\text { hyperintensit } \\
\text { y }\end{array}$ & $\begin{array}{l}\text { Cerebral } \\
\text { atrophy } \\
\text { (progressive) } \\
\text { Cerebellar } \\
\text { atrophy } \\
\text { (progressive) } \\
\text { Brainstem } \\
\text { (pontine) } \\
\text { atrophy }\end{array}$ & Not done \\
\hline
\end{tabular}




\begin{tabular}{|c|c|c|c|c|c|}
\hline & & & $\begin{array}{l}\text { (periventricu } \\
\text { lar \& } \\
\text { parieto- } \\
\text { occipital } \\
\text { white } \\
\text { matter) }\end{array}$ & $\begin{array}{l}\text { Thin corpus } \\
\text { callosum } \\
\text { T2/FLAIR } \\
\text { signal } \\
\text { hyperintensity } \\
\text { (central } \\
\text { segmental } \\
\text { tract \& } \\
\text { peritrigonal } \\
\text { regions) } \\
\text { Mega cisterna } \\
\text { magna }\end{array}$ & \\
\hline $\begin{array}{l}\text { Electroencephalogra } \\
\text { m (EEG) }\end{array}$ & Normal & Not done & 更 & $\begin{array}{l}\text { Background } \\
\text { slowing } \\
\text { (encephalopat } \\
\text { hy) } \\
\text { Epileptiform } \\
\text { activity: } \\
\text { generalized } \\
\text { and multifocal } \\
\text { spike-wave } \\
\text { (2-3 Hz) }\end{array}$ & Not done \\
\hline Histopathology & $\begin{array}{l}\text { Skeletal } \\
\text { muscle } \\
\text { biopsy: } \\
\text { normal }\end{array}$ & NR & $\begin{array}{l}\text { Central } \\
\text { nervous } \\
\text { system: } \\
\text { axonal } \\
\text { spheroids } \\
\text { Peripheral } \\
\text { nervous } \\
\text { system: }\end{array}$ & $\begin{array}{l}\text { Cutaneous } \\
\text { biopsy: } \\
\text { membranous } \\
\text { cytoplasmic } \\
\text { inclusions }\end{array}$ & Not done \\
\hline
\end{tabular}




\begin{tabular}{|c|c|c|c|c|c|}
\hline & & & $\begin{array}{l}\text { undefined } \\
\text { thickening } \\
\text { Skeletal } \\
\text { muscle } \\
\text { biopsy: } \\
\text { denervation } \\
\text { atrophy }\end{array}$ & & \\
\hline \multicolumn{6}{|l|}{ Gastrointestinal } \\
\hline $\begin{array}{l}\text { Feeding difficulties/ } \\
\text { failure to thrive }\end{array}$ & Yes & Yes & $\begin{array}{l}\text { Yes, bulbar } \\
\text { dysfunction }\end{array}$ & $\begin{array}{l}\text { Yes, bulbar } \\
\text { dysfunction }\end{array}$ & Yes \\
\hline $\begin{array}{l}\text { Nasogastric tube/ } \\
\text { gastrostomy feeding }\end{array}$ & Yes & Yes & Yes & Yes & Yes \\
\hline GI hemorrhage & Yes & Yes & Yes & Yes & No \\
\hline Other & NR & GORD & GORD & $\begin{array}{l}\text { Cyclical } \\
\text { vomiting } \\
\text { GORD }\end{array}$ & $\begin{array}{l}\text { Cyclical } \\
\text { vomiting } \\
\text { GORD }\end{array}$ \\
\hline \multicolumn{6}{|l|}{ Other } \\
\hline $\begin{array}{l}\text { Hypogammaglobulin } \\
\text { emia }\end{array}$ & $\begin{array}{l}\text { Yes, } \\
\text { IgG/IgA } \\
\text { deficiency }\end{array}$ & NR & NR & $\begin{array}{l}\text { Yes, isolated } \\
\text { IgG } \\
\text { deficiency }\end{array}$ & No \\
\hline Osteopenia & Yes & No & No & No & Yes \\
\hline Birthweight & Normal & Normal & Normal & Normal & SGA \\
\hline $\begin{array}{l}\text { Metabolic acidosis } \\
\text { with hypoglycemia }\end{array}$ & No & Yes & No & No & Yes \\
\hline Easily fatigued & NR & NR & NR & NR & Yes \\
\hline Dry eczematous skin & NR & NR & NR & NR & Yes \\
\hline \multicolumn{6}{|l|}{$\begin{array}{l}\text { Genetic mutation } \\
\text { SLC5A6 }\end{array}$} \\
\hline & $\begin{array}{l}\text { c.280C }>\text { T, } \\
\text { p. }(\text { Arg94Ter }\end{array}$ & $\begin{array}{l}\text { c.422_423del, } \\
\text { p.(Val141fs) and }\end{array}$ & $\begin{array}{l}\text { c.422_423de } \\
1\end{array}$ & $\begin{array}{l}\text { c.422_423del } \\
\text { p.(Val141fs) }\end{array}$ & c.1005+1G>A, \\
\hline
\end{tabular}




\begin{tabular}{|c|c|c|c|c|c|}
\hline & $\begin{array}{l}\text { ) and c.368 } \\
\text { G>T, } \\
\text { p.(Arg123L } \\
\text { eu) }\end{array}$ & $\begin{array}{l}\text { c.1865_1866del, } \\
\text { p.(Gln622Argfs* } \\
\text { 51) }\end{array}$ & $\begin{array}{l}\text { p.(Val141fs) } \\
\text { and } \\
\text { c.1199G >C, } \\
\text { p.(R400T) }\end{array}$ & $\begin{array}{l}\text { and } \\
\text { c.1199G>C, } \\
\text { p.(R400T) }\end{array}$ & $\begin{array}{l}\text { p.(?) and } \\
\text { c.1865_1866del, } \\
\text { p.(Gln622Argfs* } \\
\text { 51) }\end{array}$ \\
\hline \multicolumn{6}{|l|}{ Treatment } \\
\hline & $\begin{array}{l}\text { Biotin (oral) } \\
\text { 10-30 } \\
\text { mg/day } \\
\text { Pantothenic } \\
\text { acid (oral) } \\
\text { 250-500 } \\
\text { mg/day } \\
\alpha \text {-Lipoic } \\
\text { acid (oral) } \\
\text { 150-300 } \\
\text { mg/day }\end{array}$ & $\begin{array}{l}\text { Biotin (oral) } \\
\text { 10mg twice a } \\
\text { day } \\
\text { Panthothenic } \\
\text { acid (oral) } \\
\text { 250mg once a } \\
\text { day }\end{array}$ & $\begin{array}{l}\text { No } \\
\text { (deceased) }\end{array}$ & $\begin{array}{l}\text { Biotin (i.m.) } \\
10 \text { mg weekly } \\
\text { Dexpanthenol } \\
\text { (i.m.) } 250 \mathrm{mg} \\
\text { weekly } \\
\alpha \text {-lipoic acid } \\
\text { (i.v.) } 300 \mathrm{mg} \\
\text { weekly }\end{array}$ & $\begin{array}{l}\text { Biotin (oral) } \\
15 \mathrm{mg} \text { once a day } \\
\text { Pantothenic acid } \\
\text { (oral) } 300 \mathrm{mg} \\
\text { once a day } \\
\text { Lipoic acid } \\
\text { (oral) 300mg } \\
\text { once a day }\end{array}$ \\
\hline
\end{tabular}

GORD: gastroesophageal reflux disease. NR: not reported. SGA: small for gestational age. 


\section{COLD SPRING HARBOR Molecular Case Studies}

\section{A mild case of SMVT deficiency illustrating the importance of treatment response in variant classification}

Ingeborg Hauth, Hans Waterham, Ronald JA Wanders, et al.

Cold Spring Harb Mol Case Stud published online February 25, 2022

Access the most recent version at doi: $10.1101 /$ mcs.a006185

\section{Supplementary Material}

http://molecularcasestudies.cshlp.org/content/suppl/2022/03/09/mcs.a00618 5.DC1

Published online February 25, 2022 in advance of the full issue.

Accepted Manuscript

Peer-reviewed and accepted for publication but not copyedited or typeset; accepted manuscript is likely to differ from the final, published version. Published onlineFebruary 25, 2022in advance of the full issue.

Creative

Commons

License

Email Alerting Service
This article is distributed under the terms of the http://creativecommons.org/licenses/by-nc/4.0/, which permits reuse and redistribution, except for commercial purposes, provided that the original author and source are credited.

Receive free email alerts when new articles cite this article - sign up in the box at the top right corner of the article or click here. 